\title{
Decentralization, Democratization, and the Feedback Effects of Sending State Outreach
}

In 2002, the Mexican federal government unveiled the 3X1 Program. The 3X1 Program is a national social spending program whereby each level of governmentlocal, state, and federal-matches the collective remittances that migrant clubs send home, peso for peso, for public goods provision. Between 2002 and 2017, more than 28,00o public goods projects have been financed through transnational partnerships between migrant clubs and the Mexican sending state and range from urbanization and public infrastructure to parks and schools. These public goods projects are overwhelmingly implemented in poorer, rural localities in middle-income municipalities where many Mexican migrants originated and public goods are lacking. Mexico is a pioneer in the creation of public policy in which the sending state matches migrant resources for local development purposes. Since its inception, the $3 \mathrm{x} 1$ Program has served as a social spending public policy model to emulate in other countries with substantial emigration interested in tapping the diaspora for hometown investment.

When are transnational partnerships between organized migrants abroad and political officials representing the sending state more likely to occur? Specifically, why did the Mexican sending state, which historically had a laissez-faire policy toward the migrant diaspora, cultivate ties with migrant clubs to spur development in Mexico in the late 1980s and 1990s? In this chapter, I show that transnational partnerships with migrant clubs are not automatic outgrowths of international migration despite the prevalence of HTAs around the world. Rather, the processes that encourage the formation of HTAs in destination countries are affected by the particular history of migratory waves out of the origin country. I use the strategic case of Mexico to trace the historical institutional conditions that explain the 
emergence of transnational coproduction partnerships in the 1980s and 1990s and the formalization of these partnerships into the federal 3x1 Program in 2002 that continues through 2018.

First, migrant grassroots organization predated Mexican sending-state outreach. The networked nature of Mexican immigration to the United States reached a tipping point in the 1980s and 1990s and led to concentrations of Mexicans with shared ties to places of origin, which helped create HTAs and paved the way for political mobilizations in hometown communities. Moreover, during this period, factors internal to the country led to democratization and decentralization and changed conditions in ways that facilitated migrant HTA intervention in local public goods provision. In doing so, organized migrants' mobilization impelled political officials at the subnational level of government to craft new ways of engaging migrants abroad in informal coproduction schemas and later in statelevel matching grants programs. Subnational cross-border partnerships between organized migrant clubs and state-level federations of migrant clubs preceded a series of federal outreach initiatives beginning in President Salinas de Gortari's administration. The convergence of interests between migrant groups who were eager to effect change in their hometowns and that of the Mexican state led to an iterative process of negotiation that shaped the nature of the federal 3x1 Program that was eventually implemented. Eager to mobilize migrant resources toward public ends and appease migrants' discontent with the sending state, political officials at all levels of government in Mexico seized upon migrant hometown associations' bottom-up organizing and responded with top-down outreach at a critical juncture in Mexico's specific institutional history.

Data for this chapter is based on secondary data, in-person interviews, and transnational survey data. From 2009 to 2011, I interviewed local mayors in Mexico, directors of state-level 3x1 Programs, and political officials in local and state migrant affairs offices in Guanajuato, Jalisco, and Zacatecas. Additionally, I interviewed the director of the federal 3X1 Program in Mexico City and 3X1 Program coordinators and migrant outreach officers at the Los Angeles and Chicago Mexican consulates. Finally, I conducted participant observation at 3X1 project validation committee meetings (called COVAM) in Guanajuato's namesake capital and the Zacatecas State Federation building in Chicago, Illinois.

\section{THE MEXICAN-U.S. MIGRATION CORRIDOR}

Over the last century, Mexican migrants crossed the 2,00o-mile border into the richest country in the world to find higher-paying jobs and reunite with family who had previously made the sojourn abroad. Recruited by American industry during World War II, braceros (manual laborers from Mexico) worked in factories and agricultural fields throughout the Southwest, Chicago, and California on guest worker contracts. Many laborers came on guest worker visas for temporary, 
seasonal stretches and other workers permanently stayed. Many of these individuals, almost exclusively men, were directly recruited by U.S. employers. The Bracero Program brought close to 4.6 million immigrants to the U.S. and another 3 million entered in the same period without guest worker status. ${ }^{1}$

After the Bracero Program (1942-64) ended, many migrants made the brutal, dangerous journey across the Sonoran Desert and Rio Grande without papers to try and improve their lot in life. During this period, emigration from the traditional states of the rural center of Mexico was predominantly undertaken by male "pioneers" who left the countryside for jobs in the north where they made more money working the same kind of job and diversified their family income. ${ }^{2}$ Up until 1965, U.S. immigration policy restricted Mexican immigration through formal channels. But with the passage of the Hart-Cellar Act that eliminated national origins quotas for U.S. entry and the Immigration Control and Reform Act (IRCA) in 1986, more Mexicans applied for travel visas to the U.S. through family reunification provisions. Many more migrants crossed into the U.S. without documentation.

Concomitant with U.S. immigration policy changes, a series of economic shocks occurred in Mexico including the oil crisis in the late 1970s, debt crisis in the 1980s, peso currency devaluation, and passage of the North American Free Trade Agreement (NAFTA) in the 1990s. These economic shocks and the trade agreement not only imperiled the Mexican economy, but also had substantial consequences for international migration. Between 1965 and 2012, about 5-7 million Mexicans immigrated to the U.S. in search of economic opportunity and family reunification.

The IRCA was passed by Congress during the Reagan administration and was the first large-scale legalization program in U.S. history. The policy legalized the status of 2.7 million immigrants who met requirements and created a path to citizenship. Once naturalized, immigrants were granted the right to petition for family members to join them in the U.S., which had large unanticipated consequences for the number of Mexican persons immigrating through formal channels. ${ }^{3}$ Additionally, the policy increased border security, established penalties for hiring undocumented laborers, and made it a criminal offense to cross into the U.S. with fraudulent documentation or without papers. Despite enhanced border security and immigration enforcement, the structural demand for low-wage immigrant labor in the U.S., family reunification concerns, and economic crises in Mexico encouraged significantly more emigration to the U.S. after 1986.

Changes to U.S. immigration policy coincided with the financial crisis in Mexico referred to as "The Lost Decade" (La Década Perdida). Until then, the Mexican economy largely relied on windfalls from crude oil and a strategy of import substitution industrialization in which high trade barriers protected domestic companies against foreign competition. The country suffered severe setbacks when the price of petroleum plummeted in the late 1970 s and Mexico's entry 
into the General Agreement on Tariffs and Trade in 1985 exposed the economy to increased financial risk. Rampant inflation led to currency devaluation (peso crisis) and subsequent restructuring of the economy to an export-led growth strategy and loans from international banks that required conditions including scaling back federal social spending, a policy shift known as state retrenchment. The further penetration of the Mexican economy into international trade occurred in 1994 when NAFTA - the trilateral trade agreement among Mexico, the United States, and Canada-went into effect.

The elimination of trade barriers between the North American countries had important consequences for international migration. While the treaty benefitted several aspects of the Mexican economy, it was controversial legislation for the Mexican agricultural industry. Farmers were displaced from the land when staples of Mexican agriculture such as corn, beans, strawberries, and livestock could not compete with cheaper, heavily subsidized U.S. crops. Agricultural production and livestock that were once mainstays of states in the central-western region of the country ceased to be tenable employment. In response to sagging agricultural wages, droves of Mexicans left for the U.S. during this period. By 2012, about 11.4 million Mexican foreign-born persons resided in the U.S. ${ }^{4}$

The negative effects of economic instability were felt throughout Mexico and expanded the number of states sending Mexican nationals abroad in search of economic opportunity. Between 1920 and 2010, the Mexican states of Michoacán, Zacatecas, Jalisco, Guanajuato, San Luis Potosí, Durango, Guerrero, Aguascalientes, Nayarit, and Colima accounted for about half of all Mexican immigrants to the U.S. ${ }^{5}$ However, as the economic crisis spread and affected more regional economies in Mexico, emigration rates increased in the southern states such as Veracruz, Yucatán, Chiapas, and Oaxaca in the latter half of the 1990s and early 20oos. Just as the spatial distribution of Mexican migrant sending states changed, so too did immigrant destinations in the U.S. Previously, Mexican immigrants to the U.S. were concentrated in the Southwest border states and the Chicago metropolitan region. These popular immigrant destinations are referred to as traditional immigrant gateways. ${ }^{6}$ Before 1990, 85 percent of all Mexican immigrants lived in three states-Texas, Illinois, and California ${ }^{7}$ - but after 1990, migrant settlement expanded beyond traditional gateways into the Southeast, Northwest, and Northeast regions. New immigrants went directly into new destinations including Georgia, North Carolina, Utah, Washington, Iowa, Nebraska, Tennessee, and Oregon. And those immigrants already in the U.S. moved internally to new destination states and especially to the suburbs with the acquisition of more social mobility. Mexican migration became less regionalized and more of a mass phenomenon on both sides of the U.S.-Mexican border. ${ }^{8}$

Understanding the causes of international migration in the contemporary period are important for understanding the formation of hometown associations in the United States. Mexican-based immigrant organizations were first documented 
in the 1920 s and 1930 s in the U.S., but these early organizations focused mostly on support and aid to Mexican immigrants in the U.S. and Mexican cultural appreciation such as folk art, dance, sports, other recreational activities, and religion. ${ }^{9}$ These early associations were not organized around hometown ties as Mexican migration to the U.S. had not yet amassed concentrations of people who shared paisanajemeaningful social connections based on a shared sense of belonging and attachment to a common origin that emerges when immigrants encounter each other outside of the homeland. Paisanaje is a necessary and sufficient condition for the formation of migrant hometown clubs. While a few early transnational immigrant clubs were documented in U.S. gateway cities in the late 1960 s and early 1970s, it was not until the passage of U.S. immigration policy legalizing immigrant status in the U.S. that migrant transnational social networks diversified and concentrations of immigrants from the same places of origin built up over time and matured, leading to the formation and multiplication of hometown associations across U.S. cities.

\section{MEXICAN MIGRANT HOMETOWN ASSOCIATIONS IN THE UNITED STATES}

Generally, the formation of voluntary civic associations based on paisanaje is a particular feature of social networked-based migration. In the Mexican context, the social network character of international migration was a dominant feature of U.S.-bound migration but reached an apex in the 1980s and 1990s. Once migrant transnational social networks expanded and matured and concentrations of migrants from the same hometown communities proliferated, more HTAs emerged in diverse destinations across the U.S. The social network nature of U.S.Mexican migration created the conditions for filial communities in the U.S., and when it reached a tipping point, there was a widespread formation of Mexican hometown associations.

By 2003 , over 600 Mexican migrant HTAs had formed in 17 U.S. states from 26 states of origin and the Mexican federal district. ${ }^{10}$ Ten years later, over 1,200 different Mexican clubs had partnered with the Mexican government for a public goods project at least once through the federal 3x1 Program, although more than 3,00o HTAs are registered with the Institute for Mexicans Abroad. ${ }^{11}$ Contemporary migrant clubs did not begin with the singular focus of investing in the development of their hometowns. Rather, collective resources were sent back initially to support the annual patron saint festivals and church renovations in migrants' hometowns. The Catholic Church and ethno-religious institutions were an important catalyst for the formation of migrant clubs. Itinerant priests sought out paisanos from predominantly rural hometowns in the U.S. and asked them to become partners in church improvement projects. ${ }^{12}$ Other HTAs, predominantly from Chiapas and Oaxaca, formed clubs around ethno-religious obligations to the community of origin as part of the system of usos y costumbres. 
The system of usos y costumbres in indigenous Mexican communities is a system of village-based traditional governance that requires community members abroad to meet social obligations called faenas and tequios despite their physical absence. ${ }^{13}$ Making cross-border investments through hometown clubs allowed absent migrants to meet their ethno-religious obligations from the U.S., which was often a requirement for maintaining membership in the social community. ${ }^{14}$ Many migrant groups also came together on their own, first, as social, cultural, and prayers groups, soccer clubs, and rotating credit associations (referred to as tandas or cundinas). Clubs later changed their primary focus and adopted cross-border development projects, especially after emergencies and natural disasters in their hometowns. Survey data I collected of a representative sample of Mexican HTAs shows that the majority of HTAs formed on their own (67 percent) after 1990, while other clubs said they formed at the request of the Mexican local government (17 percent). Prior to 1990, before select states adopted statelevel matching grants schemes, migrant clubs that supported projects in their hometowns did so on a more informal and spontaneous basis and projects were small in scale. ${ }^{15}$

\section{WHY DO MEXICAN MIGRANTS PARTICIPATE IN HOMETOWN ASSOCIATIONS?}

The reasons for migrant participation in HTAs are multifaceted and often change over time with social mobility and experiences in the destination and origin society. While such participation is often motivated by altruism and loyalty to the hometown, it also reflects the adoption of new views brought about by the migratory process. ${ }^{16}$

Movement to a richer country provides migrants with better access to public services in addition to higher wages. As they acclimate more into U.S. society they come to expect, for example, that in an emergency a phone call to 911 summons an ambulance that will take them to a hospital. In many rural Mexican towns, there are no ambulances. In El Cerrito, Guanajuato, residents told me they had to "wait and ask a friend for a ride" or "ride horseback" to get to the closest hospital when there was an emergency. Migrants also observe and adopt new norms of behavior while living in U.S. society, bringing into starker contrast the lack of public goods provision in their places of origin. Living in the U.S. alters migrants' expectations about what kinds of public goods and services citizens in Mexico should have access to, and many start or join HTAs to modernize their hometowns in accordance with these new views.

But while speaking the language of community, migrant HTA activities also articulate that they are no longer the same as those remaining behind. ${ }^{17}$ For some migrant groups, sending money home is more akin to patronage and residents 
are viewed as the beneficiaries of migrant generosity. This view of HTA participation as a strategy for personal or group advancement is not typically the primary objective when forming or joining a club, but many migrants come to derive social status and enjoy their newfound prestige over time. Migrant clubs' development efforts sometimes come to reflect a calculated strategy aimed at cementing social differences in the origin community. ${ }^{18}$

The context of reception in U.S. society plays another role in shaping the formation of HTAs. Since many immigrants live in precarious and exploitative working conditions in the U.S. in which their identities are criminalized and marginalized, HTA engagement helps combat the vagaries of how they are perceived in the destination place. This "reactive transnationalism," as it is sometimes called, is an opportunity for migrants to feel socially connected and valued in a social community while managing the rigors of daily life abroad. ${ }^{19}$

Finally, HTA engagement may be based on the prospect of future return to the hometown. Some migrants invest in public projects for future enjoyment or to ensure that their good deeds obligate community members to care for them in old age. Migrants form HTAs to celebrate culture and play soccer and eventually adopt development projects as the central mission. Once development goals are adopted, collective remittance sending also does "relational work" for migrants. ${ }^{20}$ It signifies migrants' expressive, affective ties and serves as a tool for social status valorization in towns in which they want to eventually return.

The degree to which Mexican immigrants are involved in HTA activities also varies. For some people, occasional donations to fundraising efforts or attendance at club meetings and social events constitutes the whole of their participation in the club. Others assume a leadership role, which requires significant time, energy, skills, and resources to coordinate projects across borders. The core leadership of migrant clubs is most likely male, married, between the ages of 30 and 44 years old, with a high school degree or equivalent, and living in the U.S. between two and ten years ( 55 percent), although a sizable percent of the survey sample had lived in the U.S. just two years (18 percent) and longer than 11 years ( 25 percent). Legal status and the size of the paisano social network are all factors that help determine the scale of HTA participation. While some clubs negotiate public goods provision from afar without visiting, those individuals with legal status and who can visit the homeland more easily are more likely to be involved in the day-to-day activities of their HTA. The degree of formality of club organization and overall membership activity also varies across clubs. On average, clubs had around 100 members, but some clubs were made up of just a few families and some had up to 5,000 active members. The largest clubs were most likely to be located in California, Texas, and Illinois with a long history of Mexican immigration from the traditional sending states of Jalisco, Guanajuato, Michoacán, and Zacatecas. More information about Mexican HTAs is presented in chapter 6 and Data Appendix B. 


\section{FROM A "POLICY OF NO POLICY" TO SENDING-STATE OUTREACH INITIATIVES}

During the period of mass Mexican immigration to the U.S., Mexican emigration policy changed from a "policy of no policy" to acercamiento - the adoption of several state outreach initiatives intended to bring Mexican immigrants back into the national imaginary. Mexican state outreach policies eventually culminated in the federal 3x1 Program in 2002 for reasons only tangentially related to migration. Economic crisis spelled the beginning of the end of the PRI's 71 years of uninterrupted control of the presidency when opposition political parties began to effectively compete for state and local government. In an effort to retain national control, the PRI adopted a series of decentralization reforms devolving authority to subnational government over three terms (sexenios). ${ }^{21}$

Subnational democratization and decentralization represented two critical periods in Mexico's historic-institutional context that help explain the formation of Mexican sending-state outreach initiatives. Because of these internal political developments, Mexican leaders looked to migrants abroad and extended the reach of the corporatist state beyond the border in an attempt to appease migrants' political discontent..$^{22}$ The Mexican sending state's acercamiento project, in turn, increased the capacity of migrants to bring additional pressure on Mexican political officials to have migration programs reflect their needs and interests. The negotiation between organized migrants and state and federal Mexican officials led to the adoption of remittance matching grants programs and subsequent changes in how the programs operated.

Prior to World War II, the Mexican government's emigration policy restricted emigration through exit controls. Mexican migrants were often castigated by Mexican officials and called pochos, a derogatory term designated for "deserters" who left the homeland and lost their Mexican culture. ${ }^{23}$ In the postwar period, restrictive emigration gave way to more careful attention to those who left to participate in the Bracero Program in the U.S. labor market. However, the end of the Bracero period and failure of emigration policy to control departure ushered in a more laissez-faire attitude toward emigration that was accompanied by what many have dubbed an emigration "policy of no policy." ${ }^{24}$ The lack of policy was itself a policy that performed both as an economic, political, and demographic escape valve following severe macro-economic crises and a political crisis for the long-standing $\mathrm{PRI}$, and as an interest in releasing the pressures of rapid population growth. ${ }^{25}$

Rather than attempting to regulate departure through exit controls, emigration policy in the 1980 s and 1990 os focused instead on embracing emigrants already beyond the border. The discursive shift from denigrating emigrants as pochos to extolling them as hijos ausentes (absent sons) and heroes was accompanied by changes to emigration policy that encouraged and nurtured social, political, and economic ties to the Mexican homeland. It is in this period of acercamiento that Mexican emigration policy concentrated more on promoting development 
through remittances, extending dual nationality and absentee voting, and cementing a Mexican ethnic lobby in Washington, DC. ${ }^{26}$

Thus the ramped-up efforts of Mexican outreach to the emigrant population in the U.S. was precipitated by decentralization reforms and democratization, two critical junctures internal to Mexico that paved the way for formal development partnerships with migrants and the $3 \times 1$ Program. First, changes to the system of intergovernmental relations brought about by a series of decentralization reforms devolved political and administrative authority over public goods provision to local government. While these reforms de-centered decision-making over public service delivery to local (municipal) political officials, authorities still had to rely heavily on federal and state revenue-sharing arrangements to finance public expenditures. Looking abroad to their paisanos, municipal, state, and eventually federal tiers of government capitalized on the changing resource base of migrants abroad to help fund public works investment through transnational partnerships. Second, the opening of the political system to opposition parties at the subnational levels of government in the late 1980s and 199os created political opportunities for government actors to further encourage migrant investment in hometown development. As political competition became fiercer and incumbent parties faced legitimate threat from the opposition, delivery of public goods took on greater importance for local electoral victory. For many municipal leaders, providing public goods with matching funds from state and federal partners closed the gap in funding constraints and allowed municipal leaders to adopt more programmatic spending agendas with migrant partners.

\section{DECENTRALIZATION AND THE PROVISION OF \\ PUBLIC GOODS IN MEXICAN MUNICIPALITIES}

The De la Madrid Sexenio (1982-88)

Prior to the defeat of the PRI in the 2000 national presidential election by the popular PAN candidate Vicente Fox, the Mexican political system was dominated by one-party rule. Mexico was a strong central state with a weak federal system. Subnational political units lacked autonomy and resources and political power was concentrated in the presidency with the PRI. Until 1988, the PRI controlled all Senate seats and before 1989 no opposition party had ever won a gubernatorial election. Between 1982 and 200o, however, the PRI's lock on political control changed. Mexico experienced dramatic changes to its political institutions, spearheaded by President de la Madrid's 1984 Municipal Reform in the wake of the 1982 debt crisis.

De la Madrid's presidency initiated a profound shift from the import-substitution industrialization policies of his predecessors, which could no longer be supported by loans financed by international capital investors. During this period in which the economic system shifted to a neoliberal export-led growth strategy, 
Mexico had zero economic growth, unemployment reached 35 percent in 1985, income inequality worsened, and workers' salaries and real wages dropped to 1966 levels. While the economic crisis that began in 1982 had somewhat abated by 1990 , the economic woes that crippled Mexico during the "Lost Decade" were exacerbated again with the 1994 currency devaluation of the peso. The PRI's mismanagement of the economy galvanized calls for democratization and affected the ruling party's iron grip on political power. The national election in 1988 brought these demands to a head. Incoming president Salinas de Gortari, who succeeded De la Madrid, confronted the difficult task of restoring the PRI's power while continuing to implement free-market economic reforms and scale back the welfare state as a condition of financial loans from Washington and the international development banking community. The strategy deployed by the PRI administration was to decentralize authority to subnational levels of government in order to maintain central power and authority in the presidency. ${ }^{27}$

The economic crisis that rattled Mexico in the 1980s had iterative effects on pluralist representation at state and local levels. It also catalyzed De la Madrid's decentralization reforms. Rodriguez recalls, "by the 1980s, the façade of Mexican democracy had deteriorated so badly that the entire political system was in dire need of a facelift." ${ }^{28}$ The 1984 Municipal Reform was the regime's first response to regional economic and political imbalances that were a threat to political stability and the strength of the PRI. The processes of political opening, recognizing opposition party victories, and fiscal decentralization policies of the De la Madrid administration were pursued on the general premise that by strengthening governments at the subnational level the power and stability of the PRI presidency could be preserved. To accomplish this, the PRI recognized a smattering of opposition victories in the 1980 os and responded to demands to decentralize administrative responsibility over the delivery of public services and social welfare. The devolution of power to subnational units of government was best characterized as "unintended decentralization" and a reactive strategy: to maintain political power, the PRI had to give some away. ${ }^{29}$

The De la Madrid decentralization reforms of 1984 granted greater autonomy to municipalities and fundamentally changed the character of intergovernmental relations in Mexico. However, it was far less risky politically because it could be selectively implemented. The municipal reforms were ostensibly to pacify municipal desires for financial and political autonomy, but while the reforms granted some political power to municipal governments, lower levels of government never received full financial autonomy; subnational government did not receive an increased percentage of revenue-sharing allocations but were responsible for social spending on public goods and services.

Officially, the initiative to reform Article 115 of the Constitution, which deals with municipalities, granted administrative responsibility in the domain of public service provision for the following services: potable water and drainage, street 
lighting, street cleaning, markets and supply centers, graveyards, slaughterhouses, street paving and maintenance, parks and gardens, public security and traffic. The reform also granted municipal governments all revenues collected from property taxes (predial), fees and licenses but these revenues were marginal. Additionally, the reforms gave municipalities administrative power to design and implement development initiatives and the freedom to make formal assistance and cooperative agreements with the state and federal governments for the efficient provision of public services, if necessary. According to De la Madrid, the decentralization reforms emphasized: "Centralization in an earlier period [that] allowed the country to accelerate its economic growth and social development has outlived its usefulness and become a serious limitation on the country's national project ... Centralization has seized from the municipality the ability and the resources needed for development and the moment has come to stop this centralizing tendency" (Cámara de Diputados 1983: 8).

In practice, decentralization reforms transferred administrative authority to subnational governments but ultimately allowed the PRI to maintain control. The national presidential election held in the midst of economic crisis in 1988 and calls for more political aperture culminated in the greatest threat to the PRI's power since the creation of the party. During this period of economic and political crisis, the incoming administration looked to the Mexican migrant community abroad as one of the foreign policy strategies to improve domestic relations.

\section{The Salinas de Gortari Administration (1988-94)}

The electoral victory of Carlos Salinas de Gortari in 1988 was one of the most controversial presidential elections in Mexican history. Many people cried foul, both inside Mexico and across the border in the U.S. When Cuauhtémoc Cárdenas, former governor of Michoacán and longtime member of the PRI, failed to be nominated as the PRI's presidential candidate, he splintered from the party and coordinated a coalition to run an opposition party ticket under the National Democratic Front. The party later become the Party of the Democratic Revolution (Partido de la Revolución Democrática, PRD), a major political party contending for power at all levels of government. Veteran Chicano groups, Mexican labor unions in the U.S., exiled students and activists from the 1968 antigovernment revolt, grassroots organizations, human rights advocates, and others rallied behind Cárdenas's campaign. Cárdenas was an outspoken supporter of absentee voting rights for Mexicans in the U.S., workers' rights, economic stability, and democratization in Mexico. Cárdenas also traveled several times across the border to large emigrant and Mexican American communities in the U.S., where he campaigned in the run-up to the election.

In California and the southwestern states of Arizona and New Mexico, Cárdenas energized and mobilized an international democratic movement in his favor, enough to establish formal branches of his opposition party in the U.S. called 
comités de base (base committees). These PRD base committees fundraised extensively in select U.S. cities and encouraged PRD immigrant supporters to persuade family and friends in Mexico to cast their vote for Cárdenas. Absentee suffrage was not extended to the Mexican emigrant community during the 1988 election, despite Cardenas's efforts. However, Cárdenas's project to mobilize an active and vocal oppositional voice to the PRI on both sides of the border was effective. His engagement with migrants and Mexican Americans made it difficult for the PRI to ignore the mobilized population after 1988.

The defeat of opposition candidate Cuauhtémoc Cárdenas created widespread political division. Especially vocal were immigrants and Chicanos in the United States who supported the Cárdenas presidential campaign. While cardenismo started as a social movement, the support garnered from "discontented and disaffected" Mexicans living throughout the U.S. culminated in the emergence of the PRD as a major political party and greater support for national democratization in Mexico mounted. ${ }^{30}$ Mexican immigrants in the U.S. driven from Mexico because of economic and political problems became a natural constituency of the PRD and Cárdenas. This mobilization around the PRD forced Mexican PRI officials to recognize resentments in the Mexican community in the U.S. that felt forgotten and disenfranchised by their government. ${ }^{31}$ Cárdenas's presidential campaign in 1988 created competition between the parties for the loyalty of their compatriots as both parties searched for constituencies and allies in the U.S.

In an effort to reinforce the exceedingly fragile legitimacy of his electoral victory, Salinas revived and broadened the Mexican federal government's historically on-again, off-again acercamiento with the Mexican emigrant population. Salinas resuscitated the Mexican federal government's emigrant incorporative strategy, although he used a different mode of incorporation than in the post-revolutionary period. ${ }^{32}$ Whereas the $1917-32$ period was characterized by a policy of encouraging return, the Salinas administration directly courted migrants and their resources abroad. Salinas's contentious electoral victory mobilized opposition voices on both sides of the border that unleashed new pressure on the PRI administration to appease discontent.

The strategy adopted by the PRI was to extend services to the immigrant population in the U.S. through a series of policy initiatives including the International Solidarity Program and the Program for Migrant Communities Abroad (Programa para las Comunidades Mexicanas en el Extranjero, PCME). Salinas conceived of the International Solidarity Program as a way to create coproduction partnerships between civil society (nonstate private actors) and state officials and agency (public actors and agencies) in the Mexican government. This strategy sought to enhance state legitimacy in a way that previous coproduction programs had undermined..$^{33}$ The PCME was created in 1991 as part of the division of the Ministry of Foreign Relations (SRE). The PCME was directed by ministry staff in conjunction with consulates and Mexican cultural institutes abroad and officials regularly reached 
out to Mexican immigrants throughout the U.S. The program delivered education, community outreach, culture, recreation, and business services to migrants in the U.S. The community program, in particular, focused on helping migrants form HTAs and state-level federations of clubs and promoted state offices for migrant affairs. One of the chief activities of Mexican state offices for migrant affairs was to collect information on immigrants' whereabouts in the U.S. and publicize state-level matching funds programs to them in the states of Zacatecas, Guerrero, Jalisco, Guanajuato, and Durango. ${ }^{34}$ It is no coincidence that the number of migrant clubs surged during this period of Mexican state outreach through the PCME and International Solidarity Programs. ${ }^{35}$

The social spending cornerstone of the Salinas administration was the National Solidarity Program (Pronasol, Spanish acronym). Pronasol was originally conceived as a poverty alleviation and regional development program. The objectives of the Solidarity Program were to improve living conditions in marginalized groups, promote balanced regional development, and strengthen the participation of social organizations and local authorities through further decentralization. ${ }^{36}$ The Solidarity Program ("Solidarity") established community participation in the selection and implementation of projects through local Solidarity committees that provided a mechanism for greater citizen involvement. It also led to the creation of municipal Solidarity councils. These councils promoted greater municipal and state control over fiscal resources, autonomy over public service delivery, and social welfare programs. ${ }^{37}$ Solidarity decentralized fiscal resources and decision-making authority by allocating federal funds directly to project committees and their municipal councils instead of going through state government. While Solidarity did provide some fiscal resources directly to the municipalities for social investment, the federal revenues from income taxes were allocated to states and then to municipal government. Even as municipal governments obtained more autonomy over the administration of local budgets, they were almost entirely dependent on state and federal revenue sharing to run their jurisdictions.

The system of state-to-municipality revenue sharing called participaciones was problematic for some municipal authorities, namely rural municipalities, because of considerable variation in the actual proportional allocation of resources they received from state governments. Urban municipalities, for example, tended to receive the largest allocations of fiscal transfers, and municipalities governed by political parties other than the dominant PRI did not fare as well. Some political officials decried that the program was a mechanism for the PRI to exercise political manipulation. By rewarding PRI strongholds with public resources, municipalities financed public goods in areas with potential swing voters to capture a plurality of votes to win local elections, allegations that have been supported by extensive research on the Pronasol program..$^{3}$ Solidarity funneled resources directly to municipalities for the production of public works; however, they still relied extensively on state and federal governments for financing, and the funds 
were politically manipulated in places with different state and municipal political party affiliation.

The International Solidarity Program was one of the central, although less publicized, components of Pronasol and directly engaged the Mexican migrant diaspora in the U.S. International Solidarity was administered as a separate branch of PCME that offloaded a significant portion of infrastructure development costs to organized migrants interested in being partners in hometown development. Salinas's Solidarity programs replaced a large component of the social safety net, which was abandoned during the neoliberal shift. The programs also led to the creation of citizen committees, which contributed 50 percent to financing and implementing projects in a public-private partnership schema best described as an early form of coproduction. Migrant hometown associations were not viewed differently than citizens living in Mexico; migrant HTAs regularly served on citizen committees (albeit in the U.S.) and entered into collaborative public-private partnerships with the federal government. Between 1993 and 1997, International Solidarity coproduced 211 projects transnationally with migrant HTAs predominantly from the traditional sending state of Zacatecas.

While several migrant hometown associations predate the creation of PCME, the outreach program was another important reason why the number of HTAs and public-private partnerships increased throughout the 1990s. Immigrants who visited consulates for regular business were given information about the International Solidarity Program and PCME and how they could help develop their places of origin with collective remittances in partnership with the Mexican government. In addition, the PCME hired staff to document existing HTAs and created a directory of sports, social, religious and cultural clubs that could be converted to clubs that supported infrastructure development. ${ }^{39} \mathrm{PCME}$, in conjunction with the Mexican consulates, also arranged visits between governors of migrant sending states, municipal presidents, and their paisanos in the U.S.

According to my survey, almost a quarter of club respondents reported forming HTAs at the request of local and state Mexican officials and officials at Mexican consulates in the U.S. Moreover, PCME was responsible for the administration of applications for the consular identification cards to Mexican migrants called matricula consular cards. Federal officials collected the names and contact information of migrants who had applied for the ID cards in the U.S. That contact information was then shared with state-level agencies in Mexico, and states then combined this information with their own registries of paisanos abroad in order to have a comprehensive list of the whereabouts of migrants from home states of origin across the U.S. Additionally, at lower tiers of government, municipal administrations interviewed relatives and neighbors of emigrants to learn where they had settled in the U.S. ${ }^{40}$ Together, state officials and municipal presidents coordinated efforts, contacted their paisanos abroad, and encouraged collaborative partnerships for public goods provision using collective remittance resources. 
The PCME acted as the organizational vehicle through which municipal, state, and federal officials tapped into the financial resources of migrants for development purposes in the 1990s. The Mexican federal government's outreach efforts, administered through the PCME, were a central catalyst of migrant-state coproduction of public works through transnational partnerships with Mexican migrant HTAs. This state outreach coalesced during a period of political and economic turmoil in Mexico. During the 1980s and 1990s, municipal governments had greater political and administrative responsibility, but lacked fiscal autonomy. Creating collaborative partnerships with migrant hometown associations and using collective remittances to finance local public works was an effective strategy for many municipalities searching for innovative ways to liberate additional resources for use at local levels of governance. ${ }^{41}$

Municipalities had extraordinary opportunities to introduce changes into their political jurisdictions because of the weak institutional context in which they worked. ${ }^{42}$ During the 1990 s newly elected municipal officials had little of what Merilee Grindle referred to as "institutional memory": lack of useful records of expenditures, few instructions of how offices were to be run, lack of organizational manuals and information about pay structures for public officials or the debts of previous administrations, and no documentation of civil registry. ${ }^{43}$ These limitations inspired many municipal presidents to seek creative alternatives to the system of revenue transfers to finance public works as electoral competition increased at the local level. Even as municipal and state governments were responsible for more than half of national expenditures, they only collected around 5 percent of revenue and needed to depend on federal transfers for most of their fiscal budgets. Incomplete fiscal decentralization to subnational levels of Mexican government created the impetus for municipal and state political authorities to find creative solutions to finance their public goods mandate.

\section{Zedillo and Nuevo Federalismo (1994-2000)}

By the mid-199os Salinas's successor, PRI president Ernesto Zedillo, continued the decentralization reforms of his predecessors with the introduction of the Program of New Federalism (Nuevo Federalismo). Mexican municipalities were, by and large, responsible for the design, selection, and implementation of public service provision for their territorial jurisdiction, but still relied heavily on the fiscal resources from the state government to realize local development goals and public service delivery. The decentralization reforms that began after the economic crisis in 1982, again in 1994, and through the New Federalism under the Zedillo administration, granted municipalities more political and administrative autonomy than ever before. While political conditions changed rapidly during the 1990 s as a result of top-down changes, the federal system of revenue sharing did not change in step; political institutional changes were not part of an overarching fiscal scheme to link local, state, and federal levels of government in a strong federal system. ${ }^{44}$ 
Zedillo's decentralization strategy extended not only to lower tiers of government, but also to other branches including the judiciary and legislative branches. His administration also implemented other reforms including several procedural rules that changed the composition of Congress to reflect more proportional representation and public financing increases for opposition parties. Additionally, the access of opposition parties to mass media increased; the National Electoral Institute, the autonomous electoral management authority, became fully independent; and the powers of the federal electoral court were enhanced. The Zedillo administration continued to pursue decentralization as a means of holding onto power-in order to maintain power in the presidency they further devolved power to local and state levels of government. ${ }^{45}$

Decentralization was a politically expedient method of PRI survival. But by the midterm elections in 1997 the PRI faced a serious threat. For the first time in PRI's history they had lost control of the lower house to opposition parties. They also lost six gubernatorial elections including the important states of Jalisco, Nuevo Leon, and Guanajuato, six state legislatures, and nearly all of the largest Mexican cities to the PAN; and they also lost Mexico City to Cárdenas and the PRD. The Chamber of Deputies and other important elections to opposition parties ushered in new mandates for further dispersion of power and fiscal resources to subnational units of government. As opposition party politicians took office, they demanded more autonomy and resources from the federal government. By this point, the PRI had to concede to opposition party demands.

The economic crisis that rattled Mexico in the Lost Decade of the 1980s and early 1990 s caused a series of political, fiscal, and administrative decentralization reforms that gave subnational governments more power and autonomy than ever before. The market-oriented reforms implemented during the Zedillo administration changed political incentives for the ruling elites and made it more necessary to pay increased attention to the needs of the poor. The electoral competition at the subnational level required political candidates to honor the wishes of the electorate in order to preserve party success in future elections. By 1999, the major opposition parties governed 45.5 percent of Mexico's population at the municipal level, more than 10 state governors, and the Federal District. And, state and municipal government carried out more than half of all national expenditures through the system of federal revenue sharing and transfers. ${ }^{46}$

By the end of the Zedillo administration, the PRI's protracted rule in Mexico had started to severely wane. In order to keep the presidency, De la Madrid, Salinas, and Zedillo decentralized power to subnational levels of government. But by the late 1990s, opposition parties governed municipalities across Mexico and were directly responsible for the provision of public goods and services to the electorate, although autonomous sources of income were hard to come by. Collective remittances from migrant HTAs became a new source of revenue that municipal and state governments tapped into through the development of public policies 
directed at organized migrants in the U.S. Decentralization and democratization across local and state governments were critical antecedents in the cultivation of transnational partnerships in the provision of public works between Mexican public agencies and migrant hometown clubs abroad.

\section{STATE REMITTANCE MATCHING FUNDS PROGRAMS}

Migrant hometown associations' sponsorship of small-scale infrastructure and other community social welfare projects predate Mexican federal, state, or municipal outreach. Migrant transnational collective action was principally a grassroots phenomenon that was fairly informal and project support was sporadic across Mexico in the 1980s. But as a result of federal emigrant incorporative strategies described above, the number of HTAs and the scope of their projects increased throughout the 1990s. One of the most important reasons why hometown associations multiplied was sending state outreach and the development of state matching funds programs.

The first matching funds program originated in the state of Zacatecas. In 1986, when Genero Borrego took office as PRI governor of Zacatecas, the long-term state engagement with Zacatecano migrants in the U.S. began. Borrego actively courted migrant support for his election and during his campaign made several trips to Los Angeles and Chicago to meet with migrants and discuss the problems they confronted in the destination. One of the central tenets of his platform was to protect and advance the issues that faced Zacatecano migrants. After Borrego became governor he kept his word to migrants, declaring, "I am the governor of Zacatecas over here [in the United States] just as much as I am the governor of the Zacatecanos over there [in Zacatecas]." ${ }^{77}$ He declared November 11 the Day of the Migrant (dia del migrante) and promised to return every year to celebrate with Zacatecanos in the U.S. ${ }^{48}$

Working with a coalition of Zacatecano migrant clubs in Los Angeles, which would later become the powerful Federation of Zacatecan Clubs in southern California, Borrego and migrant leadership developed a series of matching funds programs. The state matching funds program first started with a 1x1 program in which the state cofinanced public works projects with Zacatecan migrant clubs. The state programs planted the seed for the federal 3x1 matching funds program still active today. During the Borrego administration, the informal 1X1 program would coproduce about 100 projects in 35 municipalities with 20 migrant clubs. The entire state budget for the program was only about $\$ 200,000 .{ }^{49}$

Borrego's successor, Governor Romo, was determined to continue the state relationship with organized migrant clubs. Romo met with Zacatecan HTAs early in his governorship and expanded the nascent matching funds program to an additional matching contribution from the federal government, which turned the informal 1x1 program into the official 2x1 state program. Both Borrego and Romo 
lobbied President De la Madrid and President Salinas to develop programs for Mexicans abroad. To combat the abuse and discrimination migrants were facing in the U.S., Romo advocated the expansion of the matching funds program to include a municipal contribution. Close to the end of his tenure, Romo's suggestions were heard. In 1997, the 3X1 matching funds program was formally launched in the state of Zacatecas and soon after other states including Guanajuato, Guerrero, and Jalisco followed suit.

The state $3 \mathrm{X} 1$ program in Zacatecas formalized an existing relationship between migrant clubs and the state of Zacatecas and was the beginning of a contractual commitment from the state to support migrants in the U.S. and their communities of origin. Zacatecas officially adopted a model of local economic development that not only explicitly recognized migrants, but also built on migrants' economic and social connection to their communities of origin in order to provide basic services and reduce the isolation of villages throughout the state..$^{\circ}$ Other states including Guerrero, Jalisco, and Guanajuato implemented versions of the Zacatecas matching program during the late 1990s. Migrants were no longer passive recipients of Mexican government services. Through the matching grants programs organized migrants became active negotiators in the development of social spending policies. Migrant leaders worked directly with municipal and state authorities to include provisions in the program that would give them a voice in the selection and implementation of projects.

\section{FEDERAL 3X1 PROGRAM FOR MIGRANTS}

Before he became the opposition candidate to defeat the PRI in the presidency, Vicente Fox was the PAN governor of Guanajuato. Fox built relationships with paisanos from Guanajuato, although the mode of emigrant incorporative relations was different than that employed by the PRI and PRD governors of Zacatecas. Augmenting the outreach initiatives of his predecessor, Fox was more focused on tracking, tabulating, and measuring migration and remittances. His strategy sought to channel the resources of migrants to meet state-centered priorities for economic growth and political development. For example, Fox championed the Casas Guanajuato initiative launched in 1992. Casas were a series of centers placed in large emigrant communities in the U.S. that provided services to Guanajuatense migrants similar to services provided by consulates. ${ }^{51}$ Fox's administration also established the Direccion General de Atención a Comunidades Guanajuatense en el Extranjero (DAGCE). The DAGCE was a separate state government agency that helped migrants "connect, communicate, support, and serve" their communities of origin. ${ }^{52}$ In reality, it tracked emigration and assessed the impact on high migration communities in Guanajuato. During his governorship, Fox created 18 Casas Guanajuato. ${ }^{53}$

Governor Fox also launched the Mi Comunidad program in addition to the state 2x1 matching funds program. Mi Comunidad directed remittances toward 
investment for small maquiladoras (maquilas) to be established in migrants' communities of origin. Maquilas are production plants that employ Mexican workers and import U.S. materials and equipment duty-free and tariff-free in order to assemble and finish products for export back to the U.S. The state raised initial capital investment for the maquilas and migrant clubs invested an initial \$60,000. Of the 13 maquilas that opened, 10 failed almost immediately and three continued for a couple of years after Fox left office, but only through additional subsidies from migrant clubs. Guanajuato's 2x1 remittance matching grants program created a similar arrangement in which transnational partnerships between migrant groups and the state government worked together to coproduce public works, although the state program did not include a federal matching contribution. By this point, Fox was in the throes of a heated contest for president against the PRI and the interim governor did not wish to ask for federal resources for statemigrant investment.

While the Guanajuato state 2x1 program was not as successful as other matching funds programs in Zacatecas, Guerrero, and Jalisco, for example, it was an important part of Fox's presidential campaign platform. Fox promised to take the 2x1 program nationwide and proposed to raise the matching funds to three pesos for every peso contributed by migrant HTAs. In an informal public opinion survey taken after Fox won, the promise to expand the matching funds program and existing programs for migrants in the U.S. was one of the main reasons respondents cited for backing the PAN. ${ }^{44}$ Fox was known to have invoked the 3x1 Program during presidential campaign stops in Chicago and California. ${ }^{55}$ Fox seized upon his predecessor's outreach with organized migrants abroad who wanted to engage in cross-border public goods provision in their hometown and scaled up programmatic initiatives to affect all migrants across the U.S. and their engagement with local, state, and federal levels of government.

Fox kept his promise to nationalize the $3 \times 1$ Program. Once he was elected to the presidency, he set up a cabinet position to address the demands and needs of migrants directly. Several hometown association leaders were also invited to inaugural activities and 15 leaders attended the inauguration itself. When the federal 3x1 program was launched in 2002, initially titled the Programa 3x1 Iniciativa Ciudana (Citizens Initiative), it was met with opposition from migrant HTA leadership. The migrants claimed the program was another watered-down version of Salinas and other presidents' poverty alleviation programs such as Pronasol.

The initial version of the federal program, formally administered by the Ministry of Social Development, allowed local citizen groups to also propose public goods projects and receive matching funds from municipal, state, and federal governments in addition to migrant HTAs. But this upset organized migrants' groups who had negotiated the program to be exclusively for migrants at the state level. In response, many migrants traveled to state capitals in Mexico to remind state government authorities how the program originated and pressured authorities to 
change the rules of operation. Guadalupe Gomez, president of the Federation of Zacatecan Clubs in southern California, told the state governor: "Keep the projects for the migrants. This is our program. We started it and we negotiated it ... you need to help us out." ${ }^{56}$ Raquel Sandoval, HTA president and a founding member of the Zacatecan federation, recalls: "We told them that clubs were disbanding because they no longer felt motivated to participate in a program that didn't take our voices seriously. We were frustrated with all the red tape." ${ }^{57}$ Migrants' concern was that the federal government would become further co-opted by other social and political actors and resources would be redirected from migrant-initiated projects to other groups.

Early collaborative partnerships between state authorities and migrant groups were instructive as to how a federal version of the program would be implemented. Migrants I interviewed that participated in the early years of the Zacatecan matching grants program were frustrated that state officials made decisions on project selection and implementation without much input from migrant actors. Organized migrant groups felt like they were there to subsidize the political officials' preferred projects without any decision-making authority. Early promoters of the matching grants programs wanted assurances that their autonomy would be preserved. In order to put pressure on political officials, migrant hometown association leaders threatened a remittance boycott as Fox and the 3x1 program lost credibility with the influential and increasingly organized migrant emigrant community in the U.S. Juan Hernandez, president of the Office for Mexicans Abroad, was heard telling the minister of foreign relations: "This is our last chance and there won't be another one. We have to get this right or we will have lost the migrants forever." ${ }^{8}$ Migrants used their organizational might to change the sending state's corporatist approach to cross-border public goods partnerships.

The Ministry of Social Development, the Ministry of Foreign Relations, and Fox's cabinet official for the President's Office for Migrants worked with frustrated migrant groups to amend the program and they made several concessions. First, preference for project selection was granted to migrants and not ordinary citizens in migrant hometowns. In practice, this meant that local residents were prohibited from proposing projects for cofinancing without the support and participation of a migrant club from the municipality. Second, political officials reversed initial course and allowed migrants to continue funding churches, plazas, rodeo rings, and other recreational projects in addition to public infrastructure and social welfare projects like schools and health clinics. And finally, the program was renamed the $3 x_{1}$ Program for Migrants. After 2002, the number of migrant clubs across the U.S. skyrocketed. Survey respondents reported overwhelmingly that they started their clubs after the 3X1 Program launched (75 percent of clubs formed between 2002 and 2008).

The exit of individuals from state control posed an interesting challenge and fundamental constraint on sending states..$^{59}$ Emigrants, no longer territorial residents 
of the polity, limited the sending state's capacity to use coercion, extract resources, and comply with state demands. Through the process of emigration to new political jurisdictions migrants inverted the power relationship between "state" and "society" because migrants' evolving resource base generated new political leveragesending states wanted to harness remittances, but lacked power to control how migrants spent their savings. ${ }^{60}$ Sending states tried to mobilize migrant resources toward particularistic goals in line with state preferences, but they were met with an organized migrant leadership that demanded autonomy over how their complementary resources were spent on projects in their hometowns. The formalization of transnational partnerships between organized migrant groups in the U.S. and the Mexican state through the 3x1 Program institutionalized ties between state and nonstate migrant actors for local development and granted HTAs considerable negotiating leverage in transnational partnerships.

\section{SUMMARY}

The network nature of international migration generated new forms of community based on shared social ties to place of origin commonly expressed in the formation of migrant hometown associations. As this chapter shows, specific historical waves of international migration are more likely to build up concentrations of migrant filial or sister communities in the destination country. In Mexico, the social network features of international migration followed a period of economic crises and U.S. immigration policy change, which led to family reunification through formal channels and through unauthorized entry to the U.S. Throughout the 199os and 2000 as migrants settled in destination places based on social ties, proximity to other migrants built paisanaje community and fortified shared bonds and mutual interest to help the homeland.

This process produced HTAs in the late 1990s. While many HTAs started out with a cultural, religious, and recreation focus, many clubs amended their goals to also include public goods provision in their hometowns informally and most often autonomously. As migrants' observations and expectations for public goods access changed with time spent in the U.S., social mobility led to the acquisition of resources that made it possible to improve hometowns. Through this process migrants also recognized that greater social status could be garnered through the provision of development projects back home. Many clubs shifted focus to philanthropic investments in their places of origin through the hometown club in this period of sending state outreach and the expansion of the matching grants program at the federal level.

While many HTAs formed through grassroots mobilization, evidence presented in this chapter also showed that the sending state became an important force in the formation of new clubs and public policy formation. Sending state outreach was preceded by political and economic factors internal to Mexico, which changed 
local conditions that facilitated migrant intervention in public goods provision. These domestic changes incentivized the Mexican sending state to develop new ways of relating to their citizens living abroad.

Decentralization reforms spearheaded in the late 1980 os and 1990s and subnational democratization over the same period impelled the creation of Mexican local, state, and federal sending outreach initiatives aimed at cultivating ties to organized migrant groups abroad. Outreach programs like the PCME, International Solidarity, and the state- and federal-level remittance matching programs encouraged hometown clubs to form throughout the U.S. and send money home for public goods projects in municipalities of origin. The growing role of migrant hometown associations in their communities of origin, along with the timing of decentralization and democratization in Mexico's political history, created an opportunity structure in which political officials looked abroad to Mexican immigrants to develop the homeland with resources acquired in the destination. With savings and social networks, organized migrants helped liberate resources for municipal officials and their public works budgets.

The institutionalization of transnational partnerships that accompanied the federal 3x1 program in 2002 did not develop either from migrant-led transnationalism or state-led outreach policies. Formal cross-border partnerships occurred at a critical juncture through a process of institutional reconfiguration. Tracing critical historical events that precipitated the federal launch of the subsequent 3x1 Program for Migrants, the chapter demonstrates how the process of decentralization and democratization in Mexico and the economic crisis that rattled the regional economies of migrant sending states were preconditions that explain Mexican government actors' interests in looking outward to the organized diaspora in the U.S. The formation of partnerships occurred in a window of time in which already-organized migrants were actively involved in hometown development projects. But the attention of public agencies in the sending state gave organized migrant groups new political leverage to negotiate policy changes that benefited the migrants. Sending state activities including the tracking of paisanos abroad, the formation of migrant affairs offices across Mexican states, and increased consular presence in the U.S. The $3 \times 1$ Program also worked to organize hometown associations where they did not exist before, which led to the widespread formation of over 1,500 active hometown clubs coproducing public goods and services with the sending state in half of all municipalities by 2013.

The historic-institutional analysis presented in this chapter provides a macrostructural picture of the conditions that led to the formation of transnational partnerships between migrant groups and the sending state. While the 3x1 Program administered the matching funds from local, state, and federal partners for local public goods, the program left project coordination entirely at the discretion of migrant groups and local government actors with no oversight from higher tiers of government. All facets of project coordination including the selection, budgeting, 
implementation, and oversight of projects were determined at the local level between migrant HTAs and municipal authorities. The lack of regulations regarding who made decisions on public goods projects and oversight from higher tiers of government meant that transnational partnerships varied considerably across municipalities and with many local leaders motivated to work with migrants according to electoral considerations. Local government officials and migrant clubs had to negotiate levels of engagement in project coordination across national borders, which opened up the transnational coordination of public goods process to political manipulation.

In the next three chapters, I examine why and how transnational partnership varied from place to place and over time, paying particular attention to the ways in which political institutional factors and social network relations affected the organization of coproduction partnerships. I use a processual analysis to unpack the micropolitical and social factors that combine to organize transnational partnerships. In doing so, I trace how community inclusion and government engagement interact to produce four distinct types of coproduction-substitutive, synergetic, corporatist, and substitutive partnerships-which each had important political consequences for local democratic governance across Mexican locales. 